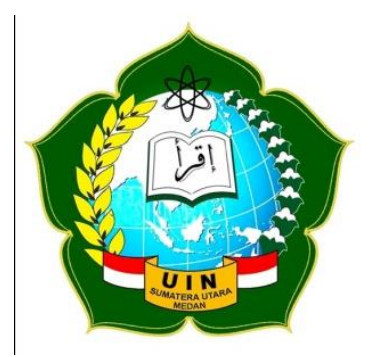

VISION JOURNAL

http://jurnaltarbiyah.uinsu.ac.id/vision

E-ISSN 2745-7982

\title{
THE EFFECT OF METACOGNITIVE STRATEGY ON STUDENTS GRAMMAR MASTERY
}

\section{Sholihatul Hamidah Daulay ${ }^{1}$, Mentari Octa ${ }^{2}$}

Email: sholihatulhamiday@uinsu.ac.id, octamentari831@gmail.com

${ }^{1,2}$ Department of English Education, State Islamic University of North Sumatera

\begin{tabular}{|l|l|}
\hline Keywords & Abstract \\
\hline grammar, if conditional & $\begin{array}{l}\text { This study was aimed to determine the grammar mastery of class } \\
\text { XI students in understanding sentence material if conditional by } \\
\text { using the metacognitive strategy learning method. Quantitative } \\
\text { research is the type of research used and uses an experimental } \\
\text { design. Researchers took data from MADRASAH ALIYAH } \\
\text { YPP RIDHO ALLAH, PERLABIAN VILLAGE. The } \\
\text { population in the school was 40 students from class XI-A and } \\
\text { XI-B, each class has 20 students. The researcher gave a pretest } \\
\text { before being given treatment and a posttest after treatment. Then } \\
\text { the researcher analyzed the data using formulas and Microsoft } \\
\text { Excel with a significance level of 0.05. Then the researchers } \\
\text { obtained data from the study, namely the results of t count (8.55) } \\
\text { t table (1.69) which means Ha is accepted while Ho is rejected. } \\
\text { The results of the study were obtained from the pretest and } \\
\text { posttest scores of students from the experimental class and } \\
\text { control class, where the posttest value in the experimental class } \\
\text { was higher than the control class. It can be found that the Ha } \\
\text { received has a significant influence on metacognitive strategies } \\
\text { on the mastery of class XI Madrasah Alwasliyah YPP Ridho } \\
\text { Allah students. }\end{array}$ \\
\hline
\end{tabular}

Faculty of Tarbiyah and Teacher Training, 1st Floor Jalan Willem Iskandar Psr V Medan, 20731

Telp. 061- 6622925 - Fax. 061 - 6615685 


\section{INTRODUCTION}

Learning English in Indonesia is a long-term task set by the Ministry of Education of the Republic of Indonesia. The importance of learning English is not something that is foreign today, this is because there are many enthusiasts or opportunities that can be found from studying English. By looking at this phenomenon, it becomes a basic thing or a big reason for the importance of learning English properly and correctly. This is also supported by the many English language courses, or English extracurricular available in schools and the many English language communities.

Language has rules in its use, including English. Grammar is the science that regulates the arrangement of sentences or words in English according to a formula. English has 4 aspects of basic skills such as: listening, reading, writing and speaking. Of the four skills, in each use, grammar should be used, so that it is easy to understand and there are no misunderstandings in communication. . Learning English about grammar is quite extensive, so it is quite difficult for students to use grammar in both verbal and nonverbal communication. As a result, students are less confident in using English because they lack understanding of grammar.

Therefore, in studying it, it is important to use the right method or strategy to support the learning process. One of them is by using a metacognitive strategy. In metacognitive strategies can stimulate students' awareness to be able to understand a lesson. In the metacognitive process linking students' awareness of their own knowledge (thinking about thinking), namely knowing things that are known and things that are not yet known.

Student awareness can be increased by providing opportunities for students to develop study plans. The purpose of lesson plans is to make it easier for students to think about what to do in the learning process. Students must be able to identify themselves by understanding their own learning abilities and procedures, as well as understanding effective learning skills. The purpose of increasing students' thinking awareness can be guided by linking students in managing their learning process, so that students improve their thinking processes about what they will do in the learning process. Students are guided to be able to understand themselves by exploring their abilities and learning procedures and knowing effective learning techniques.

Based on the description above and based on the experience of PPL 3 that has been passed, the researchers concluded to conduct research "The Effect of Metacognitive Strategy on Students' Grammar Mastery". 


\section{LITERATURE REVIEW}

\section{Grammar}

Language is a medium of communication, to convey a message in communicating the importance of good grammar so that the message can be conveyed. Grammar is mandatory and every language has its own rules. As stated by Gleason \& Ratner (2009), grammar is a combination of rules that can examine the form of sentences in applying a language. According to Lin (2010), grammar is the heart of language and is a tool t o help learners understand the target language. Because grammar contains rules of structure and interrelated word order, learners can create their own work with a grammar guide. Moreover, according to Kolln and Funk (2010:6), there are 2 types of grammar, such as Structural Grammar and Transformational Grammar:

\section{a. Structural Grammar}

Structural grammar refers to the description of terms in the language. It can be assumed that the language of the words contained in English belongs to the eight traditional languages of the Latin family. Structuralists determine in detail and objectively how the spelling sounds of sentences change and how to use functions. Another important point is that grammar emphasizes the systematic nature of English.

\section{b. Transformational Grammar}

This type of view is different from the view of the structuralisms, who study more specific sentences. This type goes deeper into a language, creating language that is not used in sentences. The description of transformational grammar is the ability to divide a basic sentence into several parts without changing the meaning.

From this explanation, a conclusion can be drawn, grammar is the main element in language, grammar acts as a guide in language rules, so that messages in sentences or languages can be understood and reduce ambiguity.

\section{-If Conditional}

The if conditional sentence is a presupposition or imagination sentence, and this sentence can express an event or imagination which in the context of the incident can be present, past or future. The if conditional sentence has 2 elements in the sentence, namely the if clause and the main clause. These sentence elements are interconnected with the main clause, 
conditional sentences state that something happens as a result of something else, or only happens when certain conditions are met.

Conditional sentences are sentences that state the terms or conditions that must be met, or sentences that state things that are contrary to factual conditions. The latter is used to express an impossible state or something we do not want to achieve, it is also used to express disappointment.

\section{-Metacognitive Strategy}

Martinis Yamin,N.(2013:4) states that learning strategies are components that must exist in the learning process so that the objectives of learning activities can be achieved. Learning strategies can be said to be a milestone or pillar of the next learning step. (Using the right learning strategies will show learning outcomes effectively.

According to Channot \& Kupper in Zhang in Suratmi, \& Purnami, A (2017:185) the metacognitive strategies thought by their subjects about learning development, structuring learning activities, monitoring obligations and assessing the level of achievement. By learning metacognitive strategies, students are guided through the questions given by the teacher, then students will use their cognitive aspects more in solving problems. Through this strategy, students will be more developed and responsible for their own performance

The learning strategy has 2 components, namely a sequence of activities that includes the application of methods and the use of various sources of strength in learning. This component will relate to the learning objectives to be achieved. By involving students, metacognitive strategies can be a reference that sharpens mental modeling. In the process of directing students, the teacher can play a role in directing students such as: a) deepening student learning skills, b) prioritizing on demonstration principles, c) exchanging ideas in dialogue, d) preparing procedures that can be learned, e) guiding students to think and think (Sanjaya, 2008:14). By being interconnected, these components can achieve indicators of each competency or material being taught.

\section{METHOD}

Researchers took the data for research at Madrasah Aliyah YPP Ridho Allah Perlabian Village, Village People's District, South Labuhan Batu Regency, North Sumatra Province for the 2020/2021 Academic Year. Researchers used quantitative methods with experimental design. 
There are 2 control and experimental classes. The experimental class is XI-A, and the control class is XI-B. The researcher gave pre-test and post-test questions with the same questions and the same level of difficulty. In the treatment section, it is the difference between the classes. For the experimental class, the researcher applied a metacognitive strategy treatment with if conditional material, while for the control class it used the teaching centered method.

In the pre-test and post-test questions, the researcher gave 20 multiple choice questions each. Students work without the help of any media, without looking at guides from books or cellphones, so the results obtained are purely from students' mastery or understanding

\section{FINDING AND DISCUSSION}

Based on the research data from the post test and pretest of 40 students of class XI MAS YPP Ridho Allah Kampung Perlabian it is known:

\section{Normality test}

Table 1.

Score of Pretest Normality

Class N LCount Ltable Status

Experiment $20 \quad 0,156 \quad 0,192$ Normal

Control $\quad 20 \quad 0,122 \quad 0,192$ Normal

The data above shows that Lcount < Ltable in both classes. In the experiment class Lcount $(0.156)<$ Ltable $(0.192)$ and in the control class Lcount $(0.122)<$ Ltable $(0.192)$. It can be concluded that the pretest scores for the control and experimental classes were normally distributed.

Table 2.

Posttest of normality experimental and control class

Class N Lhitung Ltabel Status

Experiment $20 \quad 0,165 \quad 0,192$ Normal

Control $\quad 20 \quad 0,102 \quad 0,192$ Normal 
The data above shows that the Lcount $<\mathrm{L}$ table in both classes. In the experiment class L count $(0.165)<$ Ltable $(0.192)$ and in the control class L count $(0.102)<$ Ltable $(0.192)$. for the posttest value it can be concluded that the distribution is normal.

\section{Homogenity Test}

A test used to test 2 variables or more groups of sample data obtained from populations that have the same variance.

The homogeneity test results of the pretest scores for the control class and the experimental class are:

$\mathrm{F}=($ The biggest variant $) /($ The smallest variant $)$

$\mathrm{F}=121,3158 / 113,4211=1,070$

The sum of the statistics above shows that $\mathrm{Fo}=1.070$ and $\mathrm{Ft}=4.35$. That is, Fo $(1,070)$ $<\mathrm{Ft}(4,35)$, which means that the it can be concluded that the pretest homogeneity value is homogeneous.

To find out the posttest scores in the experimental class and control class are:

$\mathrm{F}=($ The biggest variant $) /($ The smallest variant $)$

$\mathrm{F}=190,7895 / 148,6184=1,283$

The sum of the statistics above shows that $\mathrm{Fo}=1.283$ and $\mathrm{Ft}=4.35$. This means, Fo (1.283) < Ft (4.35), it can be concluded that the posttest homogeneity value is homogeneous.

\section{Hypothesis Test}

One of the conditions for the hypothesis of a study to be accepted is tcount $>$ ttable, then $\mathrm{Ha}$ is accepted and Ho is rejected. By using statistical formulas, the following are the results of the hypothesis which will be described below:

tcount $=(62,5-52,75) / \sqrt{ }((13,81+12,19) / 20)$

tcount $=9,75 / \sqrt{ } 1,3$

tcount $=9,75 / 1,14$

tcount $=8,55$

right table on $\alpha=0,05$ 
$\mathrm{dk}=(\mathrm{n} 1+\mathrm{n} 2)-2$

$\mathrm{dk}(20+20)-2=38$

because ttable 38 is not in the ttable distribution list, then there is an alternative to finding ttable with the following linear interpretation.

$30=1,697$

$40=1,684$

ttable $=1,697+(1,684-1,697) /(40-30)(38-30)$

ttable $=1,697+(-0,0104)$

ttable $=1,69$

- If tcount > ttable (0.05) then Ho is rejected and $\mathrm{Ha}$ is accepted, meaning that there is a significant influence between each variable.

- If tcount <ttable (0.05) then Ho is accepted and $\mathrm{Ha}$ is rejected, meaning that there is no significant influence between each variable.

From the calculation of the hypothesis test above, it is concluded that tcount (8.55)> ttable (1.69), which means that Ha is accepted while Ho is rejected. This means that it can be concluded that there is a significant effect of the use of metacognitive strategies on students on grammar mastery.

\section{CONCLUSION}

From the research that has been done and from the findings, that there is a significant effect of metacognitive learning strategies on students' mastery of grammar, especially on the material if it is conditional. In the results of the hypothesis tcount (8.55) > ttable (1.69), which means $\mathrm{Ha}$ is accepted while Ho is rejected. The results obtained from the post test and pretest scores with statistical calculation methods. From these results, it shows that metacognitive strategies are effective enough to be applied in learning so that students can be expected to improve English language learning and teachers can provide stimulus by students.

\section{REFERENCES}

Andrew Radford, (2009), An Introduction to English Sentence Structure, New York: Cambridge University Press 
Annur, M. F., Sujadi, I., \& Subanti, S. (2016). Aktivitas Metakognisi Siswa Kelas X SMAN 1 Tembilahan dalam Pemecahan Masalahan Matematika Ditinjau dari Gaya Kognitif. Jurnal Pembelajaran Matematika, 4(7).

Gleason,J.B \& Ratner,N.B, (2009) The Development of Language,7th edition, Boston:Allyn and Bacon

Lin,H.,C. (2010). A Case Study: An ESL Teachers Beliefs and Clasroom Practices. Kent State University: USA

Martha Kolln and Robert Funk. (2010). Understanding English Grammar: 8th :New York: Pearson

Martinis Yamin, N. (2013). Strategi dan Metode dalam Model Pembelajaran, Jakarta: DP Press Group

Suratmi, S., \& Purnami, A. S. (2017). Pengaruh strategi metakognitif terhadap kemampuan pemecahan masalah matematika ditinjau dari persepsi siswa terhadap pelajaran matematika. UNION: Jurnal Ilmiah Pendidikan Matematika, 5(2).

Wina Sanjaya. (2008). Perencanaan \& Desain Sistem pembelajaran, Jakarta: Kencana Prenadamedia 